\title{
FAKTOR-FAKTOR YANG MEMPENGARUHI PROFITABILITAS PERBANKAN SYARIAH \\ DI INDONESIA DAN MALAYSIA \\ (Meta-Analisis Penelitian di Indonesia dan Malaysia Tahun 2010-2016)
}

\author{
Ribut Pipit Agustina \\ Mahasiswa Progam Studi S1 Ekonomi Islam - Fakultas Ekonomi dan Bisnis - Universitas \\ Airlangga \\ Email: ribut.pipit-12@feb.unair.ac.id \\ Noven Suprayogi \\ Departemen Ekonomi Syariah - Fakultas Ekonomi dan Bisnis - Universitas Airlangga \\ Email: noven.suprayogi@feb.unair.ac.id
}

\begin{abstract}
:
This study focuses upon the influence between banking internal factors and economic macro on the Islamic banking profitability in Indonesia and Malaysia of the last seven years researches to determine profitability predictor variables of them. Meta-analysis techniques developed by Hunter et al. (1982) were performed to some existing studies.

Profit and loss sharing financing and interest rates of $\mathrm{BI}$ have a significant correlation to the Indonesia Islamic banking profitability, while the Capital Adequacy Ratio (CAR), Non Performing Financing (NPF), Financing to Deposit Ratio (FDR), and inflation have no significant correlation. Meta-analysis result of Islamic banking in Malaysia shows that total asset, loan to total asset, equity to total asset, expenses management, loan loss reserve to gross loan, and money supply $\left(\mathrm{M}_{2}\right)$ have a significant correlation to the profitability of Malaysia Islamic Banking, whilst liquidity (lia) and GDP have no significant correlation.
\end{abstract}

Keywords: Islamic banking profitability, meta-analysis, Banking internal factor, Macro Economics

\section{PENDAHULUAN}

Perbankan memiliki peran pentinga dalam perekonomian yaitu sebagai lembaga intermediasi masyarakat yang kelebihan dana dapat menyimpan vangnya di bank dan bank akan menyalurkan dalam bentuk kredit pada masyarakat yang membutuhkan dana. Selain itu, juga sebagai penyedia jasa kevangan perbankan antara lain Letter of Credit (L/C), Bank Garansi dan Penukaran Valuta Asing (Soemitra, 2010;87).

Perbankan yang telah lama berjalan menggunakan sistem bunga didalamnya. Bunga tersebut tidak diperbolehkan dalam prinsip syariah. Al Quran dalam Surat Ali Imran ayat 130:
Hai orang-orang yang beriman, janganlah kamu memakan Riba dengan berlipat ganda dan bertakwalah kamu kepada Allah supaya kamu mendapat keberuntungan.

Berdasarkan perintah Allah SWT tersebut, pada tahun 1963 diperkenalkan perbankan dengan prinsip syariah yang di tandai dengan berdirinya Mit Ghamr Lokal Saving Bank di Mesir. Saat ini, industri perbankan syariah dunia memiliki enam negara pemain besar yaitu Qatar, Indonesia, Saudi Arabia, Malaysia, UAE dan Turki (negara QISMUT). Indonesia dan Malaysia merupakan dua negara dari Asia Tenggara yang masuk jajaran enam negara pemain besar industri perbankan syariah di dunia, kedua negara tersebut turut berperan penting dalam pertumbuhan dan perkembangan bank 
Agustina, et al/ Jurnal Ekonomi Syariah Teori dan Terapan Vol.5 No. 7 Juli 2018: 574-589; FAKTOR-FAKTOR YANG MEMPENGARUHI PROFITABILITAS PERBANKAN SYARIAH DI INDONESIA DAN MALAYSIA (META-ANALISIS PENELITIAN DI INDONESIA DAN MALAYSIA TAHUN 2010-2016)

syariah di dunia. Selain itu, secara geografis letak kedua negara ini berdekatan dan dari segi budaya memiliki kesamaan. Sehingga perkembangan yang terjadi pada perbankan syariah di kedua negara ini menarik untuk dibandingkan.

Berdasarkan World Islamic Banking Competitiveness Report 2016, Global Market Share Indonesia sebesar 2,5\% dan malaysia sebesar $15,5 \%$. Selanjutnya, dari sisi National Market Share Indonesia sebesar 3,7\% dan Malaysia sebesar 21,3\%. Apabila dilihat dari sisi CAGR (Compound Annual Growth Rate) sebesar 29\% dan Malaysia sebesar $17 \%$. Selanjutnya, dari sisi besarnya ROA pada tahun 2014, Indonesia sebesar 1\% dan Malaysia sebesar 0,9\%. Kondisi industri perbankan syariah di kedua negara ini terangkum dalam tabel berikut:

Tabel 1.1

Kondisi Perbankan Syariah di Indonesia dan Malaysia

\begin{tabular}{|l|c|c|}
\hline & Indonesia & Malaysia \\
\hline $\begin{array}{l}\text { Global Market } \\
\text { Share }\end{array}$ & $2,5 \%$ & $15,5 \%$ \\
\hline $\begin{array}{l}\text { National Market } \\
\text { Share }\end{array}$ & $3,7 \%$ & $21,3 \%$ \\
\hline CAGR (2014) & $29 \%$ & $17 \%$ \\
\hline ROA (2014) & $1 \%$ & $0,9 \%$ \\
\hline \multicolumn{2}{|c|}{ Sumber: Worlamic Banking }
\end{tabular}

Competitiveness Report,2016

Profitabilitas penting untuk diperhatikan, karena digunakan sebagai alat evaluasi kinerja perbankan syariah dalam satu periode (Kasmir, 2014;196). Semakin tinggi profitabilitas bank maka akan semakin menarik bagi stakeholder yang memiliki kepentingan investasi maupun kredit pada bank yang bersangkutan. Sehingga faktor yang mempengaruhi profitabilitas juga memiliki urgensi untuk diketahui.

Terdapat beberapa penelitian faktor profitabilitas perbankan syariah di Indonesia dan Malaysia. Berikut ini merupakan ringkasan hasil penelitian faktor profitabilitas di Indonesia:

Tabel 1.2

Penelitian Faktor Profitabilitas Perbankan Syariah di Indonesia

\begin{tabular}{|l|l|l|}
\hline \multicolumn{1}{|c|}{ Variabel } & \multicolumn{1}{|c|}{ Signifikan } & $\begin{array}{l}\text { Tidak } \\
\text { Signifikan }\end{array}$ \\
\hline $\begin{array}{l}\text { Kecukupan } \\
\text { Modal: Capital } \\
\text { Adequacy } \\
\text { Ratio (CAR) }\end{array}$ & $\begin{array}{l}\text { Maharanie \& } \\
\text { Herianingrum } \\
\text { (2014) }\end{array}$ & $\begin{array}{l}\text { Amelia } \\
\text { (2015), } \\
\text { Wibowo \& } \\
\text { Syaichu } \\
\text { (2013) }\end{array}$ \\
\hline $\begin{array}{l}\text { Kualitas Aset: } \\
\text { Non Performing } \\
\text { Financing (NPF) }\end{array}$ & $\begin{array}{l}\text { Maharanie \& } \\
\text { Herianingrum } \\
\text { (2014) }\end{array}$ & $\begin{array}{l}\text { Amelia } \\
\text { (2015), } \\
\text { Riyadi \& } \\
\text { Yulianto } \\
\text { (2014), }\end{array}$ \\
\hline Likuiditas: (FDR) & $\begin{array}{l}\text { Riyadi \& } \\
\text { Yulianto(2014) }\end{array}$ & $\begin{array}{l}\text { Amelia } \\
\text { (2015) }\end{array}$ \\
\hline BOPO & $\begin{array}{l}\text { Amelia (2015), } \\
\text { Wibowo \& } \\
\text { Syaichu (2013) }\end{array}$ & \\
\hline $\begin{array}{l}\text { Pembiayaan } \\
\text { Bagi Hasil }\end{array}$ & $\begin{array}{l}\text { Riyadi \& } \\
\text { Yulianto } \\
\text { (2014) }\end{array}$ & $\begin{array}{l}\text { Alhamditia } \\
\text { \& Heykal } \\
\text { (2013) }\end{array}$ \\
\hline Inflasi & $\begin{array}{l}\text { Hidayati } \\
\text { (2014) }\end{array}$ & $\begin{array}{l}\text { Sodia } \\
\text { (2015) }\end{array}$ \\
\hline
\end{tabular}

Sumber: Data diolah,2017

Berikut ini merupakan ringkasan hasil penelitian faktor profitabilitas di Indonesia dan Malaysia: 
Agustina, et al/ Jurnal Ekonomi Syariah Teori dan Terapan Vol.5 No. 7 Juli 2018: 574-589; FAKTOR-FAKTOR YANG MEMPENGARUHI PROFITABILITAS PERBANKAN SYARIAH DI INDONESIA DAN MALAYSIA (META-ANALISIS PENELITIAN DI INDONESIA DAN MALAYSIA TAHUN 2010-2016)

Tabel 1.3

Penelitian Faktor Profitabilitas

Perbankan Syariah di Malaysia

\begin{tabular}{|c|c|c|}
\hline Variabel & Signifikan & $\begin{array}{c}\text { Tidak } \\
\text { Signifikan }\end{array}$ \\
\hline $\begin{array}{l}\text { Bank Size: } \\
\text { Log total } \\
\text { aset (TA) }\end{array}$ & $\begin{array}{l}\text { Husain dkk } \\
\text { (2015), Abduh \& } \\
\text { Idress (2013) }\end{array}$ & $\begin{array}{l}\text { Wasiuzzam } \\
\text { an \& } \\
\text { Tarmizi } \\
(2010)\end{array}$ \\
\hline $\begin{array}{l}\text { Likuiditas: } \\
\text { loan to } \\
\text { asset } \\
\text { ratio(LA) }\end{array}$ & $\begin{array}{l}\text { Wasiuzzaman \& } \\
\text { Tarmizi (2010) }\end{array}$ & $\begin{array}{l}\text { Husain dkk } \\
\text { (2015), } \\
\text { Chowdhury } \\
\text { (2015), } \\
\text { Kok dkk } \\
\text { (2012) }\end{array}$ \\
\hline $\begin{array}{l}\text { Kecukupan } \\
\text { Modal: } \\
\text { equity to } \\
\text { total asset } \\
\text { (EA) }\end{array}$ & $\begin{array}{l}\text { Chowdhury } \\
\text { (2015), } \\
\text { Wasiuzzaman \& } \\
\text { Tarmizi (2010) }\end{array}$ & $\begin{array}{l}\text { Husain dkk } \\
\text { (2015), } \\
\text { Abduh \& } \\
\text { Idress } \\
\text { (2013),Kok } \\
\text { dkk (2012) }\end{array}$ \\
\hline $\begin{array}{l}\text { Kualitas } \\
\text { Aset: Loan } \\
\text { Loss } \\
\text { Reserve to } \\
\text { Gross Loan } \\
\end{array}$ & $\begin{array}{l}\text { Wasiuzzaman \& } \\
\text { Tarmizi (2010) }\end{array}$ & $\begin{array}{l}\text { Husain dkk } \\
(2015), \\
\text { Abduh \& } \\
\text { Idress } \\
\text { (2013) }\end{array}$ \\
\hline $\begin{array}{l}\text { Operating } \\
\text { Efficiency: } \\
\text { BOPO }\end{array}$ & & $\begin{array}{l}\text { Abduh \& } \\
\text { Idrees } \\
\text { (2013) }\end{array}$ \\
\hline Inflasi & $\begin{array}{l}\text { Chowdhury } \\
(2015), \\
\text { Abduh \& Idress } \\
(2013), \\
\text { Wasiuzzaman \& } \\
\text { Tarmizi 2010 }\end{array}$ & $\begin{array}{l}\text { Kok dkk } \\
(2012)\end{array}$ \\
\hline $\begin{array}{l}\text { Money } \\
\text { Supply (M2) }\end{array}$ & Kok dkk (2012) & $\begin{array}{l}\text { Chowdhury } \\
(2015)\end{array}$ \\
\hline
\end{tabular}

Sumber: Data diolah,2017

Berdasarkan tabel diatas, dapat dilihat bahwa terdapat hasil penelitian yang sama pada penelitian profitabilitas perbankan syariah di Indonesia dan Malaysia yaitu variabel inflasi yang terdapat pada penelitian Sodia (2015) dan Kok dkk (2012), yang sama-sama berpengaruh tidak signifikan pada profitabilitas perbankan syariah. Selanjutnya, juga terdapat faktor yang berpengaruh pada profitabilitas perbankan syariah di Indonesia tetapi tidak berpengaruh pada profitabilitas perbankan syariah di Malaysia, seperti pada variabel BOPO yang terdapat pada penelitian Amelia (2015) dan Abduh Idrees (2013).

Selain itu, juga terdapat beberapa hasil penelitian yang tidak konsisten, baik penelitian yang berkaitan dengan faktor profitabilitas perbankan syariah di Indonesia maupun Malaysia. Maka dari itu, penulis ingin melakukan studi yang menyeluruh terhadap faktor profitabilitas perbankan syariah di Indonesia dan Malaysia. Metode yang sesuai untuk masalah ini adalah studi meta analisis. Meta analisis adalah teknik statistika yang dapat mengkaji perbedaan hasil penelitian-penelitian yang disebabkan oleh tinjauan literatur secara narasi yang dapat menyesatkan dan tidak meyakinkan, variasi ukuran sampel, periode waktu, metode penelitian dan semakin banyaknya replikasi penelitian, dimana perbedaan hasil penelitianpenelitian ini dapat menimbulkan masalah yang berkelanjutan (Fanani, 2014).

\section{LANDASAN PUSTAKA}

Menurut Undang-undang No.21 tahun 2008 perbankan syariah adalah segala sesuatu yang menyangkut tentang Bank Syariah dan Unit Usaha Syariah,mencakup kelembagaan, kegiatan usaha, serta cara dan proses dalam melaksankan kegiatan usahanya.

Menurut Dendawijaya (2003:120) salah satu cara mengukur kemampuan manajemen bank dalam memperoleh 
Agustina, et al/ Jurnal Ekonomi Syariah Teori dan Terapan Vol.5 No. 7 Juli 2018: 574-589; FAKTOR-FAKTOR YANG MEMPENGARUHI PROFITABILITAS PERBANKAN SYARIAH DI INDONESIA DAN MALAYSIA (META-ANALISIS PENELITIAN DI INDONESIA DAN MALAYSIA TAHUN 2010-2016) profitabilitas secara keseluruhan adalah rasio return on asset. Apabila return on asset bank tinggi, maka keuntungan bank dan posisi bank dari segi penggunaan aset akan semakin bagus.

Faktor internal bank adalah faktorfaktor internal bank dimana manjemen dapat melakukan campur tangan secara langsung melalui kebijakan-kebijakan yang dibuat dengan keputusankeputusan manajemen bank. Variabel yang masuk kategori faktor internal bank adalah bank size, likuiditas,opperational efficiency, kecukupan modal, kualitas aset, Aktiva Tetap Terhadap Modal, pembiayaan bagi hasil, pembiayaan jual beli, deposit, financial risk, Sertifikat Bank Indonesia Syariah, dan Penyusunan Penghapusan Aktiva Produktif. Menurut Sukirno (2010:4) kondisi makro ekonomi adalah tindakan, kegiatan dan perubahan ekonomi secara keseluruhan. Variabel makro ekonomi yaitu inflasi,nilai tukar, GDP, money supply, suku bunga dan saving on $\mathrm{GNI}$.

Hipotesis penelitian ini terbagi menjadi dua yaitu penelitian faktor profitabilitas perbankan syariah di Indonesia dan Malaysia. Berikut hipotesis penelitian profitabilitas perbankan syariah di Indonesia:

$\mathrm{H1}$ : Kecukupan modal (CAR) berpengaruh signifikan negatif.

H2: Kualitas Aset (NPF) berpengaruh signifikan negatif.

H3: Likuiditas (FDR) akan berpengaruh signifikan positif.
H4: Pembiayaan bagi hasil berpengaruh signifikan negatif.

H5: Inflasi berpengaruh signifikan positif.

H6: Suku bunga BI berpengaruh signifikan positif.

Berikut hipotesis penelitian profitabilitas perbankan syariah di Malaysia:

$\mathrm{H} 1$ : Bank size (TA) berpengaruh signifikan positif.

H2A: Likuiditas (LA) berpengaruh signifikan positif.

H2B: Likuiditas (liq) berpengaruh signifikan negatif.

H3: Kecukupan modal (EA) berpengaruh signifikan positif.

H4: Operational efficiency (EM) berpengaruh signifikan negatif.

H5: Kualitas Aset (LLRL) berpengaruh signifikan positif.

H6: Inflasi berpengaruh signifikan positif.

H7: Money supply $\left(M_{2}\right)$ berpengaruh signifikan positif.

H8: GDP berpengaruh signifikan positif.

\section{METODE PENELITIAN}

Penelitian ini meneliti tentang faktorfaktor yang mempengaruhi profitabilitas perbankan syariah di Indonesia dan Malaysia dengan metode meta analisis.

\section{Definisi Operasional Variabel}

Profitabilitas perbankan syariah diukur menggunakan return on asset. berikut rumus return on asset perbankan syariah:

$$
\mathrm{ROA}=\frac{\text { Laba Bersih }}{\text { Total Aktiva }} \times 100 \%
$$

Faktor profitabilitas perbankan syariah yang digunakan dalam penelitian ini adalah faktor internal bank dan makro ekonomi. 
Agustina, et al/ Jurnal Ekonomi Syariah Teori dan Terapan Vol.5 No. 7 Juli 2018: 574-589; FAKTOR-FAKTOR YANG MEMPENGARUHI PROFITABILITAS PERBANKAN SYARIAH DI INDONESIA DAN MALAYSIA (META-ANALISIS PENELITIAN DI INDONESIA DAN MALAYSIA TAHUN 2010-2016) Jenis dan Sumber Data

Jenis data penelitian ini adalah data sekunder yaitu penelitian yang meneliti tentang faktor yang mempengaruhi profitabilitas perbankan syariah di Indonesia dan penelitian tentang faktor yang mempengaruhi profitabilitas perbankan syariah di Malaysia. Jurnal penelitian terkait faktor profitabilitas perbankan syariah di Indonesia merupakan jurnal penelitian ekonomi yang minimal terakreditasi $C$ dengan dasar seleksi adalah SK Dirjen Dikti tentang akreditasi jurnal, sedangkan jurnal penelitian terkait faktor profitabilitas perbankan syariah di Malaysia merupakan jurnal yang terdapat pada Reseacrh Gate, Proquest, Emerald, Elsevier dan Science Direct.

Sumber data berasal dari jurnal yang terdapat di website jurnal yang dipublikasi, seperti JAMBSP, Walisongo, UG Jurnal, AKRUAL, BINUS, JAM, Diponegoro Journal of Management, e-Journal, JESTT, AAJ, Al-lqtishad, An-Nisbah, BISNIS, el-JIZYA, Journal of Islamic Economics, Banking and Finance, World Applied Sciences Journal, Australian Journal of Basic and Applied Sciences, European Journal of Islamic Finance, dan Journal of Basic and Applied Scientific Research.

\section{Metode Pengumpulan Data}

Metode pengumpulan data penelitian ini adalah dokumentasi, dimana kumpulan data sekunder yang akan digunakan dalam penelitian ini, di dalamnya termasuk kumpulan artikel dan jurnal nasional maupun internasional.
Populasi dan Sampel

Populasi penelitian ini adalah seluruh jurnal yang dipublikasikan di jurnal Indonesia dan Malaysia yang terakreditasi atau memiliki reputasi, yang menggunakan profitabilitas yang perbankan syariah sebagai variabel dependen. Penelitian ini menggunakan jurnal profitabilitas perbankan syariah yang dipublikasi dengan rentang waktu penelitian tujuh tahun sejak 2010 hingga 2016. Penelitian profitabilitas perbankan syariah di Indonesia memiliki sampel sebanyak 14 artikel dari populasi 19 artikel. Penelitian profitabilitas perbankan syariah di Malaysia memiliki sampel sebanyak 6 artikel dari populasi 8 artikel.

\section{Analisis Data}

Analisis data penelitian ini bersifat kuantitatif dengan metode meta analisis. Metode ini digunakan untuk menguji penelitian yang meneliti tentang faktor yang mempengaruhi profitabilitas perbankan syariah di Indonesia dan Malaysia. Analisis data penelitian ini ada enam langkah. Pertama, mencari jurnal tentang faktor profitabilitas perbankan syariah di Indonesia dan Malaysia. Kedua, menentukan kriteria untuk mendapatkan jurnal yang akan diuji dalam penelitian ini. Ketiga, Mengumpulkan keseluruhan hasil studi untuk memastikan bahwa tidak ada kekurangan dalam prosedur meta analisis yang akan dilakukan. Keempat, menentukan effect size atau pearson coefficient ( $r$ ). Berikut merupakan formula yang digunakan untuk mengkonversi study ke r: 
Agustina, et al/ Jurnal Ekonomi Syariah Teori dan Terapan Vol.5 No. 7 Juli 2018: 574-589; FAKTOR-FAKTOR YANG MEMPENGARUHI PROFITABILITAS PERBANKAN SYARIAH DI INDONESIA DAN MALAYSIA (META-ANALISIS PENELITIAN DI INDONESIA DAN MALAYSIA TAHUN 2010-2016)

Tabel 3.1

Formula untuk mengkonversi study ke $r$

\begin{tabular}{|c|c|c|}
\hline $\begin{array}{c}\text { Statistic } \\
\text { Tests }\end{array}$ & $\begin{array}{c}\text { Transformasi } \\
\text { formula ke } r\end{array}$ & Keterangan \\
\hline $\begin{array}{c}t- \\
\text { statistic }\end{array}$ & $r=\sqrt{\frac{t^{2}}{t^{2}+d f}} r$ & $\begin{array}{l}\dagger \text { : nilai t- } \\
\text { statistic } \\
d f: \text { degree } \\
\text { of freedom }\end{array}$ \\
\hline z-tests & $r=\sqrt{\frac{Z^{2}}{N}}$ & \\
\hline p-value & $\begin{array}{l}\text { Konversi two } \\
\text { tailed menjadi } \\
\text { one tailed, lihat } \\
\text { nilai z dalam } \\
\text { kondisi } \\
\text { probabilitas } \\
\text { normal }\end{array}$ & \\
\hline
\end{tabular}

Sumber: Lyons, 2000

Kelima, melakukan pengujian hipotesis dengan menggunakan meta analisis yaitu pertama menetukan rata-rata korelasi $r$ $\left(\overline{\mathrm{r}}=\frac{\sum\left(\mathrm{N}_{\mathrm{i}} \mathrm{r}_{\mathrm{i}}\right)}{\sum \mathrm{N}_{\mathrm{i}}}\right)$, menentukan observasi varian
$\left(S_{r}^{2}=\frac{\left.\sum\left[N_{i}\left(r_{i}-\overline{\mathrm{r}}\right)^{2}\right]\right)}{\sum N_{i}}\right)$, menentukan estimasi varian sampling eror $\left(S_{e}^{2}=\frac{\left(1-\overline{\mathrm{r}}^{2}\right)^{2} K}{\sum N_{i}}\right)$, menentukan estimasi varian populasi $\left(S_{p}^{2}=S_{r}^{2}-S_{e}^{2}\right), \quad$ menentukan interval kepercayaan sebesar 95\% $\left[\overline{\mathrm{r}}+S_{p} Z 0.975\right] \approx$ $\left[\overline{\mathrm{r}}+S_{p}(1.96)\right]$, dan menguji validitas model statistik $\left(\mathrm{X}_{\mathrm{k}-1}^{2}=\mathrm{K} \frac{\mathrm{S}_{\mathrm{r}}^{2}}{\mathrm{~S}_{\mathrm{e}}^{2}}\right)$. Langkah keenam, setelah diketahui faktor profitabilitas perbankan syariah di Indonesia dan Malaysia, kemudian membandingkan faktor profitabilitas perbankan syariah di Indonesia dengan faktor profitabilitas perbankan syariah di Malaysia. Sehingga, nantinya akan terlihat faktor profitabilitas yang sama-sama berpengaruh pada profitabilitas perbankan syariah di Indonesia dan Malaysia.

\section{HASIL DAN PEMBAHASAN}

Deskripsi Hasil Penelitian Profitabilitas Perbankan Syariah di Indonesia

Tabel 4.1

Hasil Meta Analisis Penelitian Profitabilitas Perbankan Syariah di Indonesia

\begin{tabular}{|c|c|c|c|c|c|c|c|c|c|}
\hline $\begin{array}{l}\text { Independent } \\
\text { Variable }\end{array}$ & $\sum_{\mathbf{N i}}$ & K & $\overline{\mathbf{r}}$ & $S_{r}^{2}$ & $S_{e}^{2}$ & $S_{p}^{2}$ & $\begin{array}{l}\% S_{e}^{2} \\
/ S_{r}^{2}\end{array}$ & $\begin{array}{c}\text { Confidence } \\
\text { Interval }\end{array}$ & $X_{k-1}^{2}$ \\
\hline General-CAR & 454 & 8 & $-0,0900$ & 0,0805 & 0,0173 & 0,0632 & 21,5273 & $-0,2138 ; 0,0339$ & $37,1621^{*}$ \\
\hline General-NPF & 337 & 8 & $-0,0758$ & 0,0838 & 0,0235 & 0,0603 & 27,9992 & $-0,1940 ; 0,0425$ & $28,5722^{*}$ \\
\hline General-FDR & 492 & 9 & $-0,0662$ & 0,0824 & 0,0181 & 0,0642 & 22,0117 & $-0,1922 ; 0,0597$ & $40,8874^{*}$ \\
\hline $\begin{array}{l}\text { General- } \\
\text { Pembiyaan } \\
\text { Bagi Hasil }\end{array}$ & 100 & 2 & $-0,1207$ & 0,0719 & 0,0194 & 0,0051 & 27,0056 & $-0,1307 ;-0,1107$ & $7,4059 *$ \\
\hline General-Inflasi & 155 & 3 & $-0,0253$ & 0,0709 & 0,0193 & 0,0516 & 27,2529 & $-0,1264 ; 0,0758$ & $11,0080^{*}$ \\
\hline $\begin{array}{l}\text { General-suku } \\
\text { bunga }\end{array}$ & 155 & 3 & 0,2797 & 0,0169 & 0,0164 & 0,0004 & 97,5677 & 0,$2789 ; 0,2805$ & $3,0748^{*}$ \\
\hline
\end{tabular}

*Signifikan pada 0,01

Sumber: Data diolah,2017 
Agustina, et al/ Jurnal Ekonomi Syariah Teori dan Terapan Vol.5 No. 7 Juli 2018: 574-589; FAKTOR-FAKTOR YANG MEMPENGARUHI PROFITABILITAS PERBANKAN SYARIAH DI INDONESIA DAN MALAYSIA (META-ANALISIS PENELITIAN DI INDONESIA DAN MALAYSIA TAHUN 2010-2016)

Hasil dari delapan total sampel yang diuji mengindikasikan bahwa kecukupan modal yang diukur menggunakan capital adequacy ratio (CAR) dengan profitabilitas perbankan syariah di Indonesia berpengaruh tidak signifikan $(\overline{\mathrm{r}}=$ $-0,0900)$, dengan confidence interval $95 \%$ antara $-0,2138 ; 0,0339$. Berdasarkan hasil meta analisis tersebut, maka $\mathrm{HI}$ tidak diterima.

Perhitungan chi-square $\left(\mathrm{X}_{\mathrm{k}-1}^{2}\right)$ menghasilkan nilai sebesar 37,1621, sedangkan tabel chi-square menunjukkan nilai 18,48 pada tingkat signifikasi 0,01 . Hasil perhitungan chi-square $\left(\mathrm{X}_{\mathrm{k}-1}^{2}\right)$ tersebut mengindikasikan kemungkinan eksistensi variabel variabel moderator yang mungkin mempengaruhi hasil temuan general meta-analysis. Namun, efek moderator tidak dapat ditentukan karena tidak terdapat pengukuran variabel yang dapat dibandingkan baik variabel dependen maupun explanatory. Oleh karena itu, tidak ada uji sub-group yang bisa diterapkan pada variabel capital adequacy ratio (CAR).

Hasil dari total delapan sampel studi yang diuji mengindikasikan bahwa kualitas aset yang diukur menggunakan non performing financing (NPF) dengan profitabilitas perbankan syariah di Indonesia berpengaruh tidak signifikan $(\overline{\mathrm{r}}=$ $-0,0758)$, dengan confidence interval $95 \%$ antara -0,1940;0,0425. Berdasarkan hasil meta analisis tersebut, maka H2 tidak diterima.

$$
\text { Perhitungan chi-square }\left(\mathrm{X}_{\mathrm{k}-1}^{2}\right)
$$
menghasilkan nilai sebesar 28,5722, lebih besar dari nilai tabel chi-square $\left(\mathrm{X}_{0,01}^{2}\right)$ yang sebesar 18,48. Hasil perhitungan chisquare $\left(\mathrm{X}_{\mathrm{k}-1}^{2}\right)$ tersebut mengindikasikan kemungkinan eksistensi variabel variabel moderator yang mungkin mempengaruhi hasil temuan general meta-analysis. Namun, efek moderator tidak dapat ditentukan karena tidak terdapat pengukuran variabel yang dapat dibandingkan baik variabel dependen maupun explanatory. Oleh karena itu, tidak ada uji sub-group yang bisa diterapkan pada variabel non performing financing (NPF).

Hasil dari sembilan total sampel studi yang diuji mengindikasikan bahwa likuiditas yang diukur menggunakan financing to deposit ratio (FDR) dengan profitabilitas perbankan syariah di Indonesia berpengaruh tidak signifikan $(\overline{\mathrm{r}}=$ $-0,0662$ ), dengan confidence interval $95 \%$ antara $-0,1922 ; 0,0597$. Berdasarkan temuan ini, maka $\mathrm{H} 3$ tidak diterima.

Perhitungan chi-square $\left(\mathrm{X}_{\mathrm{k}-1}^{2}\right)$ menghasilkan nilai sebesar 40,8874, lebih besar dari nilai tabel chi-square $\left(\mathrm{X}_{0,01}^{2}\right)$ yang sebesar 20,09 . Hasil perhitungan chisquare $\left(\mathrm{X}_{\mathrm{k}-1}^{2}\right)$ tersebut mengindikasikan kemungkinan eksistensi variabel variabel moderator yang mungkin mempengaruhi hasil temuan general meta-analysis. Namun, efek moderator tidak dapat ditentukan karena tidak terdapat pengukuran variabel yang dapat dibandingkan baik variabel dependen maupun explanatory. Oleh karena itu, tidak ada uji sub-group yang bisa 
Agustina, et al/ Jurnal Ekonomi Syariah Teori dan Terapan Vol.5 No. 7 Juli 2018: 574-589; FAKTOR-FAKTOR YANG MEMPENGARUHI PROFITABILITAS PERBANKAN SYARIAH DI INDONESIA DAN MALAYSIA (META-ANALISIS PENELITIAN DI INDONESIA DAN MALAYSIA TAHUN 2010-2016)

diterapkan pada variabel financing to deposit ratio (FDR).

Hasil dari dua total sampel studi yang divji mengindikasikan bahwa pembiayaan bagi hasil dengan profitabilitas perbankan syariah di Indonesia berpengaruh signifikan $(\overline{\mathrm{r}}=-0,1207)$ dengan confidence interval 95\% antara -0,1307;-0,1107. Hasil ini menunjukkan bahwa pembiayaan bagi hasil memiliki hubungan negatif terhadap profitabilitas perbankan syariah di Indonesia. Berdasarkan hasil meta analisis tersebut, maka H4 dapat diterima.

$$
\text { Perhitungan chi-square }\left(\mathrm{X}_{\mathrm{k}-1}^{2}\right)
$$
menghasilkan nilai sebesar 7,4059, lebih besar dari nilai tabel chi-square $\left(\mathrm{X}_{0,01}^{2}\right)$ yang sebesar 6,63. Hasil perhitungan chisquare $\left(\mathrm{X}_{\mathrm{k}-1}^{2}\right)$ tersebut mengindikasikan kemungkinan eksistensi variabel variabel moderator yang mungkin mempengaruhi hasil temuan general meta-analysis. Namun, efek moderator tidak dapat ditentukan karena tidak terdapat pengukuran variabel yang dapat dibandingkan baik variabel dependen maupun explanatory. Oleh karena itu, tidak ada uji sub-group yang bisa diterapkan pada variabel pembiayaan bagi hasil.

Hasil dari tiga total sampel studi yang diuji mengindikasikan bahwa inflasi dengan profitabilitas perbankan syariah di Indonesia berpengaruh tidak signifikan ( $\overline{\mathrm{r}}=$ $-0,0253)$, dengan confidence interval $95 \%$ antara $-0,1264 ; 0,0758$. Berdasarkan temuan ini, maka $\mathrm{H} 5$ tidak diterima.

Hasil perhitungan chi-square $\left(\mathrm{X}_{\mathrm{k}-1}^{2}\right)$ sebesar 11,0080, lebih besar dari tabel chi- square $\left(X_{0,01}^{2}\right)$ yang sebesar 9,21. Hasil perhitungan chi-square $\left(\mathrm{X}_{\mathrm{k}-1}^{2}\right)$ tersebut mengindikasikan kemungkinan eksistensi variabel variabel moderator yang mungkin mempengaruhi hasil temuan general meta-analysis. Namun, efek moderator tidak dapat ditentukan karena tidak terdapat pengukuran variabel yang dapat dibandingkan baik variabel dependen maupun explanatory. Oleh karena itu, tidak ada uji sub-group yang bisa diterapkan pada variabel inflasi.

Hasil dari tiga total sampel studi yang diuji mengindikasikan bahwa suku bunga berpengaruh secara signifikan dengan profitabilitas perbankan syariah di Indonesia $(\bar{r}=0,2797)$, dengan confidence interval $95 \%$ antara 0,$2789 ; 0,2805$. Hasil ini menunjukkan bahwa suku bunga memiliki hubungan positif terhadap profitabilitas perbankan syariah di Indonesia. Berdasarkan hasil meta analisis tersebut, maka $\mathrm{H} 6$ dapat diterima.

Hasil perhitungan chi-square $\left(\mathrm{X}_{\mathrm{k}-1}^{2}\right)$ sebesar 3,0748, lebih kecil dari nilai chisquare table $\left(\mathrm{X}_{0,01}^{2}\right)$ yang sebesar 9,21 pada tingkat signifikasi 0,01. Hasil perhitungan chi-square $\left(\mathrm{X}_{\mathrm{k}-1}^{2}\right)$ tersebut mengindikasikan tidak terdapat variabel moderator yang mungkin mempengaruhi hasil general meta-analysis atas variabel ini,sehingga tidak diperlukan uji sub-group. Berdasarkan hasil meta analisis dan uraian diatas, maka variabel yang menjadi faktor profitabilitas perbankan syariah di Indonesia adalah pembiayaan bagi hasil dan suku bunga. 
Agustina, et al/ Jurnal Ekonomi Syariah Teori dan Terapan Vol.5 No. 7 Juli 2018: 574-589; FAKTOR-FAKTOR YANG MEMPENGARUHI PROFITABILITAS PERBANKAN SYARIAH DI INDONESIA DAN MALAYSIA (META-ANALISIS PENELITIAN DI INDONESIA DAN MALAYSIA TAHUN 2010-2016) Deskripsi Hasil Penelitian Profitabilitas Perbankan Syariah di Malaysia

Tabel 4.2

Hasil Meta Analisis Penelitian Profitabilitas Perbankan Syariah di Malaysia

\begin{tabular}{|c|c|c|c|c|c|c|c|c|c|}
\hline & $\sum_{\mathbf{N i}}$ & K & $\overline{\mathbf{r}}$ & $S_{r}^{2}$ & $S_{e}^{2}$ & $S_{p}^{2}$ & $\% S_{e}^{2} / S_{r}^{2}$ & $\begin{array}{c}\text { Confidence } \\
\text { Interval }\end{array}$ & $X_{k-1}^{2}$ \\
\hline $\begin{array}{l}\text { General } \\
\text { - TA }\end{array}$ & 166 & 3 & 0,2795 & 0,0379 & 0,0154 & 0,0226 & 40,4940 & $\begin{array}{c}0,2352 \\
0,3237\end{array}$ & $7,4085^{*}$ \\
\hline $\begin{array}{l}\text { ROAA - } \\
\text { TA }\end{array}$ & 86 & 2 & 0,2123 & 0,0638 & 0,0212 & 0,0426 & 33,2148 & $\begin{array}{l}0,1287 ; \\
0,2959\end{array}$ & $6,0214^{*}$ \\
\hline $\begin{array}{l}\text { General- } \\
\text { LA }\end{array}$ & 275 & 4 & 0,1476 & 0,0220 & 0,0139 & 0,0080 & 63,3766 & $\begin{array}{l}0,1319 ; \\
0,1634\end{array}$ & $6,3115^{*}$ \\
\hline $\begin{array}{l}\text { ROA - } \\
\text { LA }\end{array}$ & 239 & 3 & 0,0937 & 0,0030 & 0,0123 & 0,0093 & 407,4524 & $\begin{array}{l}0,0754 ; \\
0,1119\end{array}$ & $0,7363^{*}$ \\
\hline $\begin{array}{l}\text { General } \\
\text { - Liq }\end{array}$ & 138 & 2 & $-0,0633$ & 0,0652 & 0,0144 & 0,0508 & 22,0592 & $\begin{array}{c}-0,1629 ; \\
0,0362\end{array}$ & $9,0665^{*}$ \\
\hline $\begin{array}{l}\text { General } \\
\text { - EA }\end{array}$ & 463 & 7 & $-0,1357$ & 0,0533 & 0,0146 & 0,0387 & 27,3416 & $\begin{array}{l}-0,2116 ; \\
-0,0598\end{array}$ & $\begin{array}{c}25,6020 \\
*\end{array}$ \\
\hline $\begin{array}{l}\text { ROAA - } \\
\text { EA }\end{array}$ & 86 & 2 & $-0,2922$ & 0,1039 & 0,0195 & 0,0844 & 18,7283 & $\begin{array}{l}-0,4576 \\
-0,1267\end{array}$ & $\begin{array}{c}10,6790 \\
*\end{array}$ \\
\hline $\begin{array}{l}\text { ROA - } \\
\text { EA }\end{array}$ & 377 & 5 & $-0,1000$ & 0,0349 & 0,0130 & 0,0219 & 37,2700 & $\begin{array}{l}-0,1429 ; \\
-0,0571\end{array}$ & $\begin{array}{c}13,4156 \\
*\end{array}$ \\
\hline $\begin{array}{l}\text { General } \\
-\mathrm{OE}\end{array}$ & 188 & 2 & $-0,4800$ & 0,1592 & 0,0063 & 0,1529 & 3,9587 & $\begin{array}{l}-0,7796 \\
-0,1804\end{array}$ & $\begin{array}{c}50,5213 \\
*\end{array}$ \\
\hline $\begin{array}{l}\text { General } \\
\text { - LLRL }\end{array}$ & 274 & 4 & 0,2684 & 0,0477 & 0,0126 & 0,0351 & 26,3445 & $\begin{array}{l}-0,3373 ; \\
-0,1995 \\
\end{array}$ & $\begin{array}{c}15,1834 \\
*\end{array}$ \\
\hline $\begin{array}{l}\text { ROAA - } \\
\text { LLRL } \\
\end{array}$ & 86 & 2 & $\begin{array}{c}- \\
0,2080\end{array}$ & 0,0624 & 0,0213 & 0,0411 & 34,1200 & $\begin{array}{l}-0,2886 \\
-0,1275 \\
\end{array}$ & $5,8617^{*}$ \\
\hline $\begin{array}{l}\text { ROA - } \\
\text { LLRL }\end{array}$ & 188 & 2 & $\begin{array}{c}- \\
0,2961 \\
\end{array}$ & 0,0386 & 0,0089 & 0,0297 & 22,9563 & $\begin{array}{l}-0,3543 \\
-0,2378 \\
\end{array}$ & $8,7122^{*}$ \\
\hline $\begin{array}{l}\text { General- } \\
\text { Inflasi }\end{array}$ & 275 & 5 & $-0,0240$ & 0,0535 & 0,0182 & 0,0353 & 33,9644 & $\begin{array}{c}-0,0932 \\
0,0452 \\
\end{array}$ & $\begin{array}{c}14,7213 \\
*\end{array}$ \\
\hline $\begin{array}{l}\text { ROAA- } \\
\text { Inflasi }\end{array}$ & 86 & 2 & 0,3045 & 0,0007 & 0,0191 & 0,0184 & 2735,1453 & $\begin{array}{l}0,2683 \\
0,3406\end{array}$ & $0,0731^{*}$ \\
\hline $\begin{array}{l}\text { ROA- } \\
\text { Inflasi }\end{array}$ & 189 & 3 & $-0,1734$ & 0,0061 & 0,0149 & 0,0089 & 246,3394 & $\begin{array}{l}-0,1908 \\
-0,1560\end{array}$ & $1,2178^{*}$ \\
\hline $\begin{array}{l}\text { General- } \\
\text { Money } \\
\text { supply }\end{array}$ & 159 & 2 & 0,2251 & 0,0009 & 0,0113 & 0,0105 & 1333,273 & $\begin{array}{l}0,2046 ; \\
0,2457\end{array}$ & $0,1500^{*}$ \\
\hline $\begin{array}{l}\text { General- } \\
\text { GDP }\end{array}$ & 275 & 5 & 0,0562 & 0,0640 & 0,0181 & 0,0459 & 28,2416 & $\begin{array}{c}-0,0338 \\
0,1462 \\
\end{array}$ & $\begin{array}{c}17,7044 \\
*\end{array}$ \\
\hline $\begin{array}{l}\text { ROAA- } \\
\text { GDP }\end{array}$ & 86 & 2 & 0,1166 & 0,0726 & 0,0226 & 0,0499 & 31,1787 & $\begin{array}{l}0,0187 ; \\
0,2145\end{array}$ & $6,4146^{*}$ \\
\hline $\begin{array}{l}\text { ROA- } \\
\text { GDP }\end{array}$ & 189 & 3 & 0,0287 & 0,0576 & 0,0158 & 0,0418 & 27,4916 & $\begin{array}{c}-0,0532 \\
0,1106\end{array}$ & $\begin{array}{c}10,9124 \\
*\end{array}$ \\
\hline
\end{tabular}

*Signifikan pada 0,01

Sumber: Data diolah,2017

Hasil dari tiga total sampel studi yang diuji mengindikasikan bahwa bank size yang diukur menggunakan log total aset berhubungan secara signifikan dengan profitabilitas perbankan syariah di Malaysia $(\overline{\mathrm{r}}=0,2795)$, dengan confidence interval $95 \%$ antara 0,$2352 ; 0,3237$. Hasil ini menunjukkan bahwa bank size yang 
Agustina, et al/ Jurnal Ekonomi Syariah Teori dan Terapan Vol.5 No. 7 Juli 2018: 574-589; FAKTOR-FAKTOR YANG MEMPENGARUHI PROFITABILITAS PERBANKAN SYARIAH DI INDONESIA DAN MALAYSIA (META-ANALISIS PENELITIAN DI INDONESIA DAN MALAYSIA TAHUN 2010-2016)

diukur menggunakan log total aset

memiliki hubungan positif terhadap profitabilitas perbankan syariah di Malaysia. Berdasarkan temuan ini, $\mathrm{HI}$ dapat diterima.

Hasil perhitungan chi-square $\left(\mathrm{X}_{\mathrm{k}-1}^{2}\right)$ sebesar 7,4085, lebih kecil dari nilai tabel chi-square $\left(X_{0,01}^{2}\right)$ yang sebesar 9,21 . Nilai tersebut mengindikasikan tidak terdapat variabel moderator yang mungkin mempengaruhi hasil general metaanalysis atas variabel ini, sehingga tidak diperlukan uji heterogenitas.

Hasil dari empat total sampel studi yang diuji mengindikasikan bahwa likuiditas yang diukur menggunakan loan to total asset (LA) berhubungan secara signifikan dengan profitabilitas perbankan syariah di Malaysia $(\overline{\mathrm{r}}=0,1476)$, dengan confidence interval $95 \%$ antara 0,$1319 ; 0,1634$. Hasil ini menunjukkan bahwa likuiditas yang diukur menggunakan loan to total asset (LA) memiliki hubungan positif terhadap profitabilitas perbankan syariah di Malaysia. Berdasarkan temuan ini, H2A dapat diterima. Hasil perhitungan chisquare $\left(X_{k-1}^{2}\right)$ sebesar 6,3115 , lebih kecil dari nilai critical value of chi-square $\left(\mathrm{X}_{0,01}^{2}\right)$ yang sebesar 11,34. Nilai tersebut mengindikasikan tidak terdapat variabel moderator yang mungkin mempengaruhi hasil general meta-analysis atas variabel ini, sehingga tidak diperlukan uji heterogenitas.

Hasil dari dua total sampel studi yang diuji mengindikasikan bahwa likuiditas yang diukur menggunakan liquid asset to total liabilities (Liq) dengan profitabilitas perbankan syariah di Malaysia berpengaruh tidak signifikan $(\overline{\mathrm{r}}=-0,0633)$, dengan confidence interval $95 \%$ antara 0,$1629 ; 0,0362$. Berdasarkan temuan ini, H2B tidak diterima.

Hasil perhitungan chi-square $\left(\mathrm{X}_{\mathrm{k}-1}^{2}\right)$ sebesar 9,0665, lebih besar dari nilai tabel chi-square $\left(\mathrm{X}_{0,01}^{2}\right)$ yang sebesar 6,63. Nilai tersebut mengindikasikan kemungkinan eksistensi variabel moderator yang mungkin mempengaruhi hasil temuan general meta-analysis. Namun, efek moderator tidak dapat ditentukan karena tidak terdapat pengukuran variabel yang dapat dibandingkan, baik variabel dependen maupun explanatory. Oleh karena itu, tidak terdapat uji sub-group yang bisa diterapkan pada variabel liquid asset to total liabilities (Liq).

Hasil dari tujuh total sampel studi yang diuji mengindikasikan bahwa kecukupan modal yang diukur menggunakan equity to total asset (EA) berpengaruh signifikan dengan profitabilitas perbankan syariah di Malaysia $(\bar{r}=-0,1357)$, dengan confidence interval 95\% antara -0,2116;-0,0598. Hasil ini menunjukkan bahwa kecukupan modal yang diukur menggunakan equity to total asset (EA) memiliki hubungan negatif terhadap profitabilitas perbankan syariah di Malaysia. Berdasarkan temuan ini, H3 tidak diterima.

Hasil perhitungan chi-square $\left(\mathrm{X}_{\mathrm{k}-1}^{2}\right)$ sebesar 25,6020, lebih besar dari nilai tabel chi-square $\left(\mathrm{X}_{0,01}^{2}\right)$ yang sebesar 16,81 . Nilai tersebut mengindikasikan kemungkinan eksistensi variabel moderator yang 
Agustina, et al/ Jurnal Ekonomi Syariah Teori dan Terapan Vol.5 No. 7 Juli 2018: 574-589; FAKTOR-FAKTOR YANG MEMPENGARUHI PROFITABILITAS PERBANKAN SYARIAH DI INDONESIA DAN MALAYSIA (META-ANALISIS PENELITIAN DI INDONESIA DAN MALAYSIA TAHUN 2010-2016) mungkin mempengaruhi hasil temuan general meta-analysis. Namun, hasil yang konsisten juga terdapat pada dua uji subgroup yaitu ROAA dan ROA. Kedua uji sub-group tersebut sama-sama mendukung hasil dari general metaanalysis yaitu kecukupan modal yang diukur menggunakan equity to total asset (EA) berpengaruh signifikan negatif terhadap profitabilitas perbankan syariah di Malaysia.

Hasil dari dua total sampel studi yang diuji mengindikasikan bahwa operational efficiency yang diukur menggunakan expenses management (EM) berhubungan secara signifikan dengan profitabilitas perbankan syariah di Malaysia $(\bar{r}=-0,4800)$, dengan confidence interval $95 \%$ antara $-0,7796 ;-0,1804$. Hasil ini menunjukkan bahwa operational efficiency yang diukur menggunakan expenses management (EM) memiliki hubungan negatif terhadap profitabilitas perbankan syariah di Malaysia. Berdasarkan temuan ini, H4 dapat diterima.

Hasil perhitungan chi-square $\left(\mathrm{X}_{\mathrm{k}-1}^{2}\right)$ sebesar 50,5213, lebih besar dari nilai tabel chi-square $\left(X_{0,01}^{2}\right)$ yang sebesar 6,63 . Nilai tersebut mengindikasikan kemungkinan eksistensi variabel moderator yang mungkin mempengaruhi hasil temuan general meta-analysis. Namun, efek moderator tidak dapat ditentukan karena tidak terdapat pengukuran variabel yang dapat dibandingkan, baik variabel dependen maupun explanatory. Oleh karena itu, tidak terdapat uji sub-group yang bisa diterapkan pada variabel expenses management (EM).

Hasil dari empat total sampel studi yang diuji mengindikasikan bahwa kualitas aset yang diukur menggunakan loan loss reserve to gross loan (LLRL) berhubungan secara signifikan dengan profitabilitas perbankan syariah di Malaysia $(\overline{\mathrm{r}}=-0,2684)$, dengan confidence interval $95 \%$ antara 0,3373;-0,1995. Hasil ini menunjukkan bahwa kualitas aset yang diukur menggunakan loan loss reserve to gross loan (LLRL) memiliki hubungan negatif terhadap profitabilitas perbankan syariah di Malaysia. Berdasarkan temuan ini, H5 tidak diterima.

Hasil perhitungan chi-square $\left(\mathrm{X}_{\mathrm{k}-1}^{2}\right)$ sebesar 15,1834, lebih besar dari nilai tabel chi-square $\left(\mathrm{X}_{0,01}^{2}\right)$ yang sebesar 11,34. Nilai tersebut mengindikasikan terdapat variabel moderator yang mungkin mempengaruhi hasil general metaanalysis atas variabel ini, sehingga diperlukan uji subgroup. Namun, hasil yang konsisten juga terdapat pada dua uji sub-group yaitu antara ROAA dan ROA. Kedua uji subgroup tersebut sama-sama mendukung hasil dari general meta analisis yaitu kualitas aset yang diukur menggunakan loan loss reserve to gross loan (LLRL) berpengaruh signifikan negatif terhadap profitabilitas perbankan syariah di Malaysia.

Hasil lima total sampel studi yang diuji mengindikasikan bahwa inflasi dengan profitabilitas perbankan syariah di Malaysia tidak signifikan $(\bar{r}=-0,0240)$, dengan confidence interval $95 \%$ antara - 
Agustina, et al/ Jurnal Ekonomi Syariah Teori dan Terapan Vol.5 No. 7 Juli 2018: 574-589; FAKTOR-FAKTOR YANG MEMPENGARUHI PROFITABILITAS PERBANKAN SYARIAH DI INDONESIA DAN MALAYSIA (META-ANALISIS PENELITIAN DI INDONESIA DAN MALAYSIA TAHUN 2010-2016)

0,0932;0,0452. Berdasarkan temuan ini, H6 tidak diterima.

Hasil perhitungan chi-square $\left(\mathrm{X}_{\mathrm{k}-1}^{2}\right)$ sebesar 14,7213, lebih besar dari tabel chisquare $\left(\mathrm{X}_{0,01}^{2}\right)$ yang sebesar 13,28 . Nilai tersebut mengindikasikan terdapat variabel moderator yang mungkin mempengaruhi hasil general metaanalysis atas variabel ini, sehingga diperlukan uji sub-group. Berdasarkan hasil uji sub-group antara ROAA dengan inflasi menunjukkan bahwa inflasi berpengaruh positif terhadap profitabilitas perbankan syariah di Malaysia. Hasil yang berbeda juga terdapat pada uji sub-group antara ROA dengan inflasi menunjukkan bahwa inflasi berpengaruh signifikan negatif terhadap profitabilitas perbankan syariah di Malaysia. Ketiga uji diatas menunjukkan hasil yang tidak konsisten, oleh karena itu dibutuhkan lebih banyak studi empiris untuk diuji.

Hasil dari dua total sampel studi yang diuji mengindikasikan bahwa money supply berhubungan secara signifikan dengan profitabilitas perbankan syariah di Malaysia $(\overline{\mathrm{r}}=0,2251)$, dengan confidence interval $95 \%$ antara 0,$2046 ; 0,2457$. Hasil ini menunjukkan bahwa money supply memiliki hubungan positif terhadap profitabilitas perbankan syariah di Malaysia. Berdasarkan temuan ini, H7 diterima.

Hasil perhitungan chi-square $\left(\mathrm{X}_{\mathrm{k}-1}^{2}\right)$ sebesar 0,1500, lebih kecil dari nilai tabel chi-square $\left(X_{0,01}^{2}\right)$ yang sebesar 6,63. Nilai tersebut mengindikasikan tidak terdapat variabel moderator yang mungkin mempengaruhi hasil general metaanalysis atas variabel ini, sehingga tidak diperlukan uji heterogenitas.

Hasil dari lima total sampel studi yang diuji mengindikasikan bahwa GDP dengan profitabilitas perbankan syariah di Malaysia berpengaruh tidak signifikan $(\bar{r}=$ 0,0562 ), dengan confidence interval $95 \%$ antara $-0,0338 ; 0,1462$. Berdasarkan temuan ini, $\mathrm{H} 8$ tidak diterima.

Hasil perhitungan chi-square $\left(\mathrm{X}_{\mathrm{k}-1}^{2}\right)$ sebesar 17,7044 , lebih besar dari nilai tabel chi-square $\left(X_{0,01}^{2}\right)$ yang sebesar 13,28 pada tingkat signifikasi 0,01 . Nilai tersebut mengindikasikan terdapat variabel moderator yang mungkin mempengaruhi hasil general meta-analysis atas variabel ini, sehingga diperlukan uji sub-group. Berdasarkan hasil uji sub-group antara ROAA dengan GDP menunjukkan bahwa GDP berpengaruh positif terhadap profitabilitas perbankan syariah di Malaysia. Hasil yang berbeda juga terdapat pada uji sub group antara ROA dengan GDP menunjukkan bahwa GDP berpengaruh tidak signifikan terhadap profitabilitas perbankan syariah di Malaysia, dimana uji sub-group pada variabel ROA memiliki hasil yang sama dengan hasil general meta analisis. Oleh karena itu variabel ini membutuhkan lebih banyak studi empiris untuk diuji. Berdasarkan hasil meta analisis diatas, variabel yang menjadi faktor profitabilitas perbankan syariah di Malaysia adalah log total aset, loan to total aset, equity to total aset, expenses management, loss Reserve to Gross Loan, dan money supply $\left(\mathrm{M}_{2}\right)$. 
Agustina, et al/ Jurnal Ekonomi Syariah Teori dan Terapan Vol.5 No. 7 Juli 2018: 574-589; FAKTOR-FAKTOR YANG MEMPENGARUHI PROFITABILITAS PERBANKAN SYARIAH DI INDONESIA DAN MALAYSIA (META-ANALISIS PENELITIAN DI INDONESIA DAN MALAYSIA TAHUN 2010-2016) Rangkuman Hasil Penelitian Profitabilitas Perbankan Syariah di Indonesia dan Malaysia

Tabel 4.3

Rangkuman Hasil Penelitian

\begin{tabular}{|c|c|c|c|c|c|}
\hline & Indonesic & & & Malaysia & \\
\hline & Faktor Internal & ank & & Faktor Internal Bo & \\
\hline No. & Faktor & Hasil & No. & Faktor & Hasil \\
\hline 1. & $\begin{array}{l}\text { Likuiditas: financing } \\
\text { to deposit ratio }\end{array}$ & Tidak signifikan & 1. & $\begin{array}{l}\text { Likuiditas: } \\
\text { Loan to total asset }\end{array}$ & Signifikan positif \\
\hline & & & & Liq & Tidak signifikan \\
\hline & & & 2. & $\begin{array}{l}\text { Bank Size: } \\
\text { log total aset }\end{array}$ & Signifikan positif \\
\hline 2. & $\begin{array}{l}\text { Kecukupan modal: } \\
\text { capital adequacy } \\
\text { ratio (CAR) }\end{array}$ & Tidak signifikan & 3. & $\begin{array}{l}\text { Kecukupan Modal: } \\
\text { Equity to total aset }\end{array}$ & $\begin{array}{l}\text { Signifikan } \\
\text { hegatif }\end{array}$ \\
\hline 3. & $\begin{array}{l}\text { Pembiayaan Bagi } \\
\text { Hasil }\end{array}$ & $\begin{array}{l}\text { Signifikan } \\
\text { negatif }\end{array}$ & 4. & $\begin{array}{l}\text { Operational Efficiency: } \\
\text { Expenses Management }\end{array}$ & $\begin{array}{l}\text { Signifikan } \\
\text { hegatif }\end{array}$ \\
\hline 4. & Kualitas Aset: NPF & Tidak signifikan & 5. & $\begin{array}{l}\text { Kualitas Aset: Loan Loss } \\
\text { Reserve to Gross Loan }\end{array}$ & $\begin{array}{l}\text { Signifikan } \\
\text { negatif }\end{array}$ \\
\hline & Faktor Makro Ek & nomi & & Faktor Makro Ekonom & \\
\hline 5. & Suku Bunga BI & Signifikan positif & 6. & Money Supply $\left(\mathrm{M}_{2}\right)$ & Signifikan positif \\
\hline 6. & Inflasi & Tidak signifikan & 7. & Inflasi & Tidak signifikan \\
\hline & & & 8. & GDP & Tidak signifikan \\
\hline
\end{tabular}

Faktor internal bank antara

perbankan syariah di Indonesia dan Malaysia tidak terdapat kesamaan. Hal tersebut terjadi karena terdapat perbedaan pada beberapa variabel yang digunakan pada artikel atau jurnal antara penelitian profitabilitas perbankan syariah di Indonesia dan Malaysia yang dijadikan sebagai data penelitian, seperti pada penelitian profitabilitas perbankan syariah di Indonesia pembiayaan bagi hasil merupakan salah satu faktor internal bank dan memiliki hubungan signifikan negatif terhadap profitabilitas perbankan syariah di Indonesia, sedangkan penelitian profitabilitas perbankan syariah di Malaysia pembiayaan bagi hasil tidak terdapat pada faktor internal bank. Selanjutnya juga terdapat variabel bank size yang diukur menggnakan log total aset dan operational efficiency yang diukur menggunakan

expenses management) dijadikan sebagai faktor internal bank dalam penelitian profitabilitas perbankan syariah Malaysia, namun tidak dijadikan sebagai faktor internal bank pada penelitian profitabilitas perbankan syariah di Indonesia.

Selain itu terdapat perbedaan rasio pengukuran pada masing-masing variabel karena rasio pengukuran pada setiap variabel yang digunakan pada artikel atau jurnal antara penelitian profitabilitas perbankan syariah di Indonesia dan Malaysia yang dijadikan sebagai data penelitian ini memiliki rasio pengukuran yang berbeda pada masing-masing variabel, seperti variabel kecukupan modal pada penelitian profitabilitas perbankan syariah di Indonesia diukur menggunakan CAR, sedangkan pada penelitian profitabilitas perbankan syariah di Malaysia diukur menggunakan rasio EA. Hal tersebut juga terjadi pada variabel 
Agustina, et al/ Jurnal Ekonomi Syariah Teori dan Terapan Vol.5 No. 7 Juli 2018: 574-589; FAKTOR-FAKTOR YANG MEMPENGARUHI PROFITABILITAS PERBANKAN SYARIAH DI INDONESIA DAN MALAYSIA (META-ANALISIS PENELITIAN DI INDONESIA DAN MALAYSIA TAHUN 2010-2016)

likuiditas dan kualitas aset. Penelitian profitabilitas perbankan syariah di Indonesia menggunakan FDR untuk mengukur variabel likuiditas, sedangkan penelitian profitabilitas perbankan syariah di Malaysia menggunakan rasio LA dan liq.

Untuk faktor makro ekonomi, inflasi merupakan satu-satunya faktor makro ekonomi yang memiliki hasil sama pada penelitian profitabilitas perbankan syariah di Indonesia dan Malaysia yaitu tidak berpengaruh signifikan, sedangkan untuk variabel suku bunga $\mathrm{BI}$ hanya terdapat pada penelitian profitabilitas perbankan syariah di Indonesia dan memiliki hasil berpengaruh signifikan positif pada profitabilitas perbankan syariah di Indonesia. Hal tersebut juga terjadi pada

\section{SIMPULAN}

Berdasarkan hasil meta analisis, variabel yang menjadi faktor profitabilitas perbankan syariah di Indonesia adalah pembiayaan bagi hasil dan suku bunga.

Berdasarkan hasil meta analisis, variabel yang menjadi faktor profitabilitas perbankan syariah di Malaysia adalah bank size (TA), likuiditas (LA), money supply $\left(M_{2}\right)$, kecukupan modal (EA), operational efficiency (EM), dan kualitas aset (LLRL).

Berdasarkan hasil meta analisis, hanya variabel inflasi saja yang memiliki hasil yang sama yaitu inflasi berpengaruh signifikan pada profitabilitas perbankan

\section{DAFTAR PUSTAKA}

Abduh, Muhamad \& Yameen Idrees. 2013.

Determinants of Islamic Banking Profitability in Malaysia. Australian variabel money supply $\left(\mathrm{M}_{2}\right)$ yaitu hanya terdapat pada penelitian profitabilitas perbankan syariah di Malaysia dan memiliki hasil berpengaruh signifikan positif pada profitabilitas perbankan syariah di Malaysia.

Penyebab lain adanya perbedaan variabel antara profitabilitas perbankan syariah di Indonesia dan Malaysia adalah terbatasnya artikel atau jurnal yang dijadikan sebagai data penelitian, sehingga ada variabel yang tidak dapat diuji menggunakan meta analisis, seperti variabel GDP pada penelitian profitabilitas perbankan syariah di Indonesia yang hanya terdapat pada satu jurnal saja, hal tersebut terjadi karena jurnal yang lain tidak memenuhi kriteria untuk dilakukan meta analisis.

syariah di Indonesia maupun Malaysia. Hasil variabel lain menunjukkan bahwa terdapat perbedaan variabel antara profitabilitas perbankan syariah di Indonesia dan Malaysia yang disebabkan oleh perbedaan pengukuran rasio pada setiap variabel yang ada pada penelitian di Indonesia dan Malaysia, jumlah data penelitian yang terbatas dan terdapat beberapa variabel yang terdapat di penelitian profitabilitas di Indonesia namun tidak terdapat pada penelitian profitabilitas Malaysia, begitu juga sebaliknya.

Journal of Basic and Applied Sciences, VII (2): 204-210. 
Agustina, et al/ Jurnal Ekonomi Syariah Teori dan Terapan Vol.5 No. 7 Juli 2018: 574-589; FAKTOR-FAKTOR YANG MEMPENGARUHI PROFITABILITAS PERBANKAN SYARIAH DI INDONESIA DAN MALAYSIA (META-ANALISIS PENELITIAN DI INDONESIA DAN MALAYSIA TAHUN 2010-2016)

Abdurrahman dkk. 2014. Analisis Pengaruh Jumlah Kredit Mikro yang Diberikan dan Non Performing Loan Terhadap Profitabilitas pada PT.Bank Syariah Mandiri KCP Buleleng Periode Tahun 2012-2013. e-Journal S1 Ak Universitas Pendidikan Ganesha, II (1).

Alhamditia, Era Rizkita \& Mohamad Heykal. 2013. Analisis Estimasi dan Faktor-faktor yang Memengaruhi Tingkat Profitabilitas Bank Umum Syariah di Indonesia. Binus Business Review, IV (1): 186-196.

Amelia, Erika. 2015. Financial Rasio and Its Influence to Profitability in Islamic Banks. Al lqtishad, VII (2): 229-240.

Chowdhury, Mohammad Ashraful Ferdous. 2015. Which is more important in terms of Profitability of Islamic Banks: Bank Specific factors or Macroeconomic factors? An Empirical Study on Malaysian Islamic Banks. Bangladesh. Departement of Business Administration. Shahjajalal University of Science \& Technology.

Chua, Siti Zulaiha Mund Zamri. 2012. Determinants of Islamic Banks Profitability in Malaysia. Berjaya Adira Institution Centre.

Dahliawati, Anne \& Muhammad Muchlis Febrianto. 2012. Analisis Pengaruh Capital Adequacy Ratio (CAR) dan Aktiva Tetap Terhadap Modal (ATTM) Terhadap Profitabilitas (ROA) pada PT.Bank " $X$ " Syariah Periode 2009-2011. UG Jurnal, VI (11).
Dendawijaya, Lukman. 2003. Manajemen Perbankan. Edisi: 2. Jakarta: Ghalia Indonesia.

Fanani, Zaenal. 2014. Karakteristik Perusahaan dan Corporate Governance terhadap Manajemen Laba: Studi Analisis Meta. Jurnal Kevangan dan Perbankan, XVIII(2): 181-200.

Hakiim, Ningsukma \& Haqiqi Rafsanjani. 2016. Pengaruh Internal Capital Adequacy Ratio (CAR), Financing To Deposit Ratio (FDR), dan Biaya Operasional Per Pendapatan Operasional (BOPO) dalam Peningkatan Profitabilitas Industri Bank Syariah di Indonesia. Jurnal Aplikasi Manajemen, XIV(1): 161-168.

Hidayati, Amalia Nuril. 2014. Pengaruh Inflasi, BI Rate dan Kurs Terhadap Profitabilitas Bank Syariah di Indonesia. An-Nisbah, I (1): 72-97.

Hunter, J.E., and F.L.Schmidt. 1990. Methods of Meta Analysis: Correcting Error and Bias in Research Findings. Beverly Hills, CA:Sage.

Husain, Azira dkk. 2015. The Internal Determinants of Islamic Banks Profitability in Malaysia. Journal of Basic and Applied Scientific Research. $\vee(7)$ : 17-21.

Idris, Asma Rashidah dkk. 2011. Determinant of Islamic Banking Institutions Profitability in Malaysia. World Applied Sciences Journal 12.

Kasmir. 2014. Analisis Laporan Kevangan. Jakarta: Rajawali Persada. 
Agustina, et al/ Jurnal Ekonomi Syariah Teori dan Terapan Vol.5 No. 7 Juli 2018: 574-589;

FAKTOR-FAKTOR YANG MEMPENGARUHI PROFITABILITAS PERBANKAN SYARIAH DI INDONESIA

DAN MALAYSIA (META-ANALISIS PENELITIAN DI INDONESIA DAN MALAYSIA TAHUN 2010-2016)

Kok, Yoke Teng dkk. 2012. The

Determinants of Islamic Banks

Profitability in Malaysia. Malaysia.

Faculty of Business and Finance.

Universiti Tunku Abdul Rahman.

Lyons, Larry C. 2000. Meta Analysis: Methods of Accumulating Results Accross Research Domains. Email Solomon@mnsinc.com

Maharanie, Mega Ayu \& Sri Herianingrum.

2014. Pengaruh Kecukupan Modal,

Fungsi Intermediasi, Pembiayaan

Bermasalah, dan Biaya Operasional

Terhadap Profitabilitas Industri Bank

Syariah Periode Januari 2010-

Desember 2012. JEST, I ( 2).

Ma'isyah, Rifqul \& Imron Mawardi. 2015.

Pengaruh Kecukupan Modal, Fungsi Intermediasi, Efisiensi Operasional, dan Pembiayaan Bermasalah Terhadap Profitabilitas: Studi pada Bank Syariah Periode Januari 2010Juli 2014. JEST, II (3): 249-265.

Pramuka, Bambang Agus. 2010. FaktorFaktor yang Berpengaruh Terhadap Tingkat Profitabilitas Bank Umum Syariah. Jurnal Akuntansi, Manajemen Bisnis dan Sektor Publik (JAMBSP), VII (1): 63-79.

Riyadi, Slamet \& Agung Yulianto. 2014. Pengaruh Pembiayaan Bagi Hasil, Pembiayaan Jual Beli, Financing to Deposit Rasio dan Non Performing Financing Terhadap Profitabilitas Bank Umum Syariah di Indonesia. AAJ, III(4): 466-474.

Sodiq, Amirus. 2015. Pengaruh Variabel Makro Ekonomi Terhadap Profitabilitas Bank Syariah di Indonesia Periode 2009-2014. BISNIS, III (2): 343-363.

Soemitra, Andri. 2010. Bank dan Lembaga Kevangan Syariah. Edisi 1. Jakarta: Kencana Prenada Media Group.

Sukirno. Sadono. 2010. Teori Pengantar Ekonomi Makro. Jakarta: PT.Raja Grafindo Persada.

Suryani. 2011. Analisis Pengaruh Financing to Deposit Ratio (FDR) Terhadap Profitabilitas Perbankan Syariah Di Indonesia. Walisongo, XIX(1): 47-74.

Swandayani, Desi Marilin \& Rohmawati Kusumaningtias. 2012. Pengaruh Inflasi, Suku Bunga, Nilai Tukar Valas dan Jumlah Uang Beredar Terhadap Profitabilitas pada Perbankan Syariah di Indonesia Periode 20052009. AKRUAL, III (2): 147-166.

Ubaidillah. 2016. Analisis Faktor-Faktor yang Mempengaruhi Profitabilitas Bank Syariah di Indonesia. el-JIZYA: Jurnal Ekonomi Islam, IV(1): 151-188.

Wasiuzzaman, Shaista \& Hanimas Ayu B† Ahmad Tarmizi. 2010. Profitability of Islamic Banks in Malaysia: An Empirical Analysis. Journal of Islamic Economics, Banking and Finance, VI (4).

Wibowo, Edhi Satriyo \& Muhammad Syaichu. 2013. Analisis Pengaruh Suku Bunga, Inflasi, CAR, BOPO, NPF Terhadap Profitabilitas Bank Syariah. Diponegoro Journal of Management, II (2): 1-10.

www.bi.go.id

www.ey.com 